\title{
BONA SPES
}

José Gatti Universidade Federal de Santa Catarina Universidade Tuiuti do Paraná

The main campus of the University of Cape Town is definitely striking, possibly one of the most beautiful in the world. It rests on the foot of the massive Devil's Peak; not far from there lies the imposing Cape of Good Hope, a crossroads of two oceans. Accordingly, the university's Latin motto is Bona Spes. With its neoclassic architecture, the university has the atmosphere of an enclave of British academic tradition in Africa. The first courses opened in 1874; since then, the UCT has produced five Nobel prizes and it forms, along with other well-established South African universities, one of the most productive research centers in the continent.

I was sent there in 2009, in order to research on the history of South African audiovisual media, sponsored by Fapesp (Fundação de Amparo à Pesquisa do Estado de São Paulo). I received an especially warm welcome and I soon realized that Brazilian researchers had been rare at UCT. Every morning I had a batch of DVDs to examine, a selection carefully prepared by the friendly staff of the African

\begin{tabular}{|l|l|l|l|l|}
\hline Ilha do Desterro & Florianópolis & n 61 & p. 011- 027 & jul/dez 2011 \\
\hline
\end{tabular}


Studies Library. As I watched those precious films, they would often interrupt me with a new title or some new information that could help my work: "Are you watching De Voortrekkers, the 1916 film about the Afrikaner pioneers? I believe you will enjoy seeing Sacrifice of Blood, made in 1918, which gives a different perspective on the same time period". I had already programmed to watch Sacrifice of Blood, but of course I was touched by their care and anticipated its screening. That showed me how important it was, for them, to express their desire for recognition, after decades of international isolation that resulted from the policies of apartheid.

Apartheid was officially installed with the victory of the white nationalist Afrikaners in the elections of 1948, but it was being practiced (more or less informally) since colonial times. The issuing of special passports for black and colored individuals, which restrained their movements within the country, for example, had already been established by English authorities since the early nineteenth century. When the Afrikaner nationalists seized power, that practice was officially adopted and enforced by the state.

Throughout the twentieth century we learned that South Africa and that South Africans of European origin were held accountable for apartheid. There is even a streak of historical information that claims that concentration camps were invented in South Africa by the British, during the Boer Wars, who imprisoned thousands of Afrikaners and their families. But after the elections of 1948, the country found itself in a rather peculiar position regarding international relations. World War II had ended and the memories of the Holocaust were still too fresh to be ignored; therefore, the institutionalization of apartheid was regarded as retrograde, as much as brutal. From 
then on, the country suffered from various international boycotts -liberal-minded artists refused to have their work shown in South Africa; athletes were forbidden or refused to perform there; finally, in the 1980s, the United Nations promoted economic sanctions. In other words, in the eyes of the media, during the second half of the twentieth century, South Africa became the repository of many of the evils that actually plagued many other countries in the world. However, now we realize that in many ways what the future of South Africa holds is also in the future of the world.

Apartheid was officially abolished in 1991 with the new, multirracial and democratic dispensation, but it persists and pervades human relations at all levels, as a symptom of a painful and slow process towards change. South African actor John Kani reminds us that "apartheid divides the way of thinking". 'Therefore, every discussion on contemporary South African culture, literature or media will have to deal with a discussion of apartheid, its ideological underpinnings and ramifications.

In the new social pact for a new nation, under the aegis of Nelson Mandela, all South African ethnic groups were invited to take part in a process which produced, in 1996, one of the most democratic constitutions in the world. After years of struggle against apartheid, South Africans were awarded a progressive project of the nation; now they had a new struggle before them, that is, a struggle for the implementation of that project. Thus, if we thought we had the theoretical tools to approach, understand and explain apartheid, we are now faced with the need for new ways to understand a formidable, unforseen phenomenon, which mobilizes the whole (new) nation.

In that process, progressive Afrikaner leaders and intellectuals found themselves in a crucial role and faced the task of redefining their own community. When I first visited the campus of UCT, 
my host, Prof. Martin Botha (whose work is included in this anthology) insisted on affirming that "UCT has to be seen as an African university", despite the European aspirations of many of his colleagues. For a foreigner like me, it was somehow paradoxical to hear those words from a blond and blue-eyed man who, first and foremost, is proud of his African heritage. Being an African, for Botha and many progressive South Africans, is an identity that should not be defined along color lines.

In his autobiographical account My Traitor's Heart, the writer Rian Malan argues that the Afrikaners, or Boers, became a "white tribe", whose ties with Europe thinned out during the colonial period and who had to find their own strategies of survival, far from the support of the European metropolis. ${ }^{2}$ Malan's approach may lack anthropological rigor but it can be read as poetically suggestive. The proclaimed bond of the Afrikaners with the African soil may explain the habit of going about barefoot, common to Afrikaners of all social classes. It is not rare to see well-dressed families getting off expensive automobiles, only to stroll barefoot in shopping malls. The Afrikaans term rooinek (meaning "redneck") was derisively used by the Boer to describe the British soldiers, because their skin would be too sensitive to the harsh African sun, unlike their own, Afrikaner skin.

That sense of belongingness had to be reformulated in the context of the post-apartheid so-called Rainbow Nation, a nation that, after all, demanded a new definition of what it meant to be South African. And after 1991, that was a task for all South Africans. Concerning that task, Afrikaner poet Antjie Krog (who also contributed her writing to this issue of Ilha), once asked "How does one find the past tense of the word hate?" And she went on:

... How do we become released into understanding, into becoming whole among others? How do we make whole? How 
close can the nose curve to tenderness; the cheek to forgiveness? How do we sound of the same breath? Hearing the the words of all the world next to each other on the same wide tableshivering the color of human. We have to hear each other's scalp and smell, each other's blood and baled belonging. We have to learn the deepest sound of each other's kidneys in the night.

We have to become each other, or forever lose the spine of being. ${ }^{3}$

In the 2001 census, the population of 48 million identified themselves as black Africans (79,5\%), whites (9,2\%), coloreds (8,9\%), Hindu or Asian (2,5\%). There were also 5 million immigrants (and/or refugees) from African countries, 3 million from Zimbabwe alone; many of them suffering from xenophobic surges from South Africans who have to deal with rising rates of unemployment.

Moreover, South Africa (now officially) constitutes a highly polyglotic environment. When I started my research, I had not fathomed the problematic of poliglossia (as well as heteroglossia) in the South African context. I had already published essays on languages regarding Brazilian and North American cinemas, but I believe now very few national cinemas or literatures have to face a challenge as tremendous as the one of South Africa's. In fact, South African social or cultural positionings are not only demarcated by "color lines"; the language one speaks at home, the accent one enunciates, the vocabulary one employs give a definite form to these positionings-and, speaking in Bakhtinian terms, shape literature and media. That cultural wealth can be heard-and seen-in films and television series, which often feature subtitles in different languages.

For if during apartheid only Afrikaans and English were the official languages, now the state recognizes eleven different languages. Zulu is the most widely spoken language, by $23 \%$ of the population 
and mostly in the region of KwaZulu-Natal. It is followed by Xhosa, which is the native language of Nelson Mandela and is spoken by $18 \%$ of the population. Afrikaans is spoken by $14 \%$ of South Africans and English, though recognized as the language of commerce and science, is spoken at home by only $9 \%$ of the population. ${ }^{4}$ That may change in the near future, since the adoption of English can be detected among certain groups, such as colored families of the Cape province, who were traditionally Afrikaans speakers but have chosen to speak English at home, in order to secure a professional future for their children. Despite the heteroglotic differences, English has a unifying role which still tends to expand in the context of global economy. At the same time, the flow of immigration has brought other languages from neighbouring countries, such as Portuguese, French and Swahili.

The main building of the main campus of UCT is the imposing colonnade of the Library (with over one million three hundred thousand volumes), which sits on top of a steep hill. From there, on sunny days, one can view the distant Cape Flats, dotted by housing projects and townships (a local term for favela) and, in the far background, the lush vineyards of the Cape and the Langeberg range, lightly snowcapped in the Winter. The students crowd the steps below the colonnade and turn it into a vibrant space of spontaneous socialization on campus. It is a hopeful view: young people of all ethnicities, who represent the three major racial groups once separated by apartheid: whites (of European origin), blacks (most of them of Bantu origin) and coloreds (whose families used to be classified as mixed and who can also be grouped as Christian or Muslim $)^{5}$ 
As of 2009, 23,500 students were enrolled, of which 6,700 $(28,5 \%)$ were postgraduate students. The ratio between male and female students is almost exactly 50:50. Today, over 50\% of the student body are non-white; international students account for $19 \%$ of total student enrollment at 4,300, representing over 100 countries, most of them of the African continent. UCT employs approximately 4,500 staff members of whom $44 \%$ are academic staff, the rest are administrative and support staff. In 2007, UCT had 866 permanent academic staff members. Between $85 \%$ and $90 \%$ of academic staff hold doctoral or masters qualifications. The proportion of non-white academic staff is currently around $23 \%$.

To a more alert observer, however, that crowd on the steps of the Library can be revealing: whites seem to interact exclusively with whites; blacks with blacks, coloreds with coloreds. There is hardly any conversation between different ethnic groups; the students, despite the elbow-to-elbow sharing of the space, seem to keep it carefully segregated. There is no hostility, just a polite understanding of one's boundaries. The same spatiality is featured in the library, at the cafeterias and on the buses. Of course, activities such as sports events, ballroom dancing and capoeira classes are very interactive and definitely show the possibilities of a new society. ${ }^{6}$ But in the classroom, for example, tensions can arise. Sometimes white students may refuse to read black authors, and vice-versa. In 2009, at a public high school in Cape Town, Xhosa students demonstrated against the teaching of their language to their white and colored colleagues, for they would rather keep Xhosa as a "secret" means of communication within their group. In many ways, such behavior echoes social and racial hierarchies that are very much alive in South African society and, not unlike our own problems in Brazil concerning race and social class, this situation will only change in a course of generations. 
However, from what I could gather, Brazilians who live in South Africa often hear the locals refer to the Brazilian mestiçagem as a model to follow-regardless of the fact that Brazil is plagued by its own forms of racism.

Nevertheless, the University of Cape Town has a history marked by the opposition to conservativeness. During the apartheid era, the university consistently opposed the racist regime and became a bastion of liberalism and racial integration. And even though affirmative action is now mandatory in South Africa, UCT started putting it into practice long before the end of apartheid. The first women were admitted in 1886; the first black students, in the 1920s. Due to this stance, UCT suffered pressure from the racist regime and had its main campus invaded by the police in 1987 .

For too many years most of the (rather scarce) information we received from South Africa came from US and UK sources. We learned about the struggle against apartheid; we listened to Myriam Makeba, Abdullah Ibrahim, Ladysmith Black Mambazo and Johnny Klegg; we read some excellent South African writers. However, that was usually the result of decisions made in publishing houses, news agencies and recording companies of the northern hemisphere.

Today, we still have a South-South gap to bridge, even though the world is somewhat more familiar with the cultural output of South Africa. Two Nobel prize winners-Nadine Gordimer and J. M. Coetzee-and authors of Afrikaner and English origins such as Alan Paton, Athol Fugard, Breyten Breytenbach, André Brink, Antjie Krog and others have achieved international recognition. And now, after apartheid, black and colored authors are more widely recognized, such as Sindiwe Magona (she writes both in English and Xhosa) and 
Rayda Jacobs (who belongs to the community of Cape Muslims). And of course, the most translated black author from South Africa is Nelson Mandela, also known in South Africa as Madiba (his Xhosa clan name).

As for audiovisual media-such an imporant means of building a country's image-, South Africa imported films from Hollywood, but South African films were mainly directed to the domestic market. Most of the images the world received of South Africa were featured in foreign films about South Africa, but invariably shot elsewhere, mostly for political reasons. Up until 1991, only a handful of films included blacks and coloreds in casts or crews, and whenever foreign black stars came to South Africa to shoot a film-such as Sidney Poitier on more than one occasion-they were not allowed to stay in hotels or eat at restaurants; sometimes they were not allowed to enter the country at all.

After 1948, the regime subsidized the production of films in Afrikaans, directed to the local public and which hardly reached screens abroad. Afrikaner films underwent specific censorship and had to abide by specific rules: characters of different ethnicities, for instance, could not be shown sharing the same frame; thus, in order to portray their eventual dialogue, filmmakers had to resort to careful shot/countershot editing. To this day, DVD stores in South African cities display some of these films in Afrikaans, which do not feature subtitles in English or any other language.

During apartheid years, controversial and powerful South African films such as Katrina (1969) and Jannie Totsiens (1970), both directed by Jans Rautenbach, and which discussed racial politics during the harshest years of the regime, were not easily distributed abroad. On the other hand, The Gods Must Be Crazy (1981) became a worldwide box-office hit. This problematic comedy, directed by Jamie 
Uys, managed to promote an edulcorated version of South African racial relations at the same time it kept racial hierarchies intact.

Today, local film and television industries still lack professionals of different ethnic and linguistic origins that can assure the representation of the diversity featured by the South African cultural landscape and thus new generations of filmmakers are being prepared by new schools around the country. Moreover, the country is also on the track of other anglophone countries such as Australia and New Zealand, whose film industries have grown considerably in the past years and have opened opportunities for British and North American productions.

In the past years, South African cinema has also won important awards throughout the world. Films such as Triomf (acclaimed in Cannes, 2008), U-Karmen Kayelitsha (Golden Bear for best film in Berlin, 2006) and District 9 (screened in major Brazilian cities for many weeks in 2009 and which is being regularly programmed on television) have won international recognition. At the same time, talents keep on leaving the country for better opportunities, such as actors John Kani, Richard E. Grant (originally from Swaziland), Charlize Theron (who won an Oscar), and the director Gavin Hood, who established a career in Hollywood and directed Tsotsi (another Oscar-winner), X-Men: Wolverine and other mainstream films.

On the other hand, local productions have also been contributing to a deep revision of South African history in the past few years, toppling myths and consecrated concepts. A good example is the documentary Hidden Heart, directed by Cristina Karrer, which had a low-profile release in 2009. That film challenges one of the most cherished myths of the apartheid era: that of the pioneer heart transplant, performed in 1967 by the Afrikaner physician Christiaan Barnard, alumnus of the University of Cape Town. In South Africa, 
people still wonder why Barnard was never awarded a Nobel prize for that feat. But the surgery, as shown in the film, was performed by the Xhosa Hamilton Naki, who was employed as a gardener at the Groote Schuur Hospital. As in so many stories of the apartheid years, Barnard received international acclaim, while Naki died as a poor man.

Among other recent works that could be cited here as examples of a new vision of South Africa are White Wedding (2009), Sea Point Days (2008) and Proteus (2003). White Wedding was a huge, overnight box-office hit, which made more public than its competitor X-Men on its first weekend of screening in most major cities in South Africa. It was directed by Jann Turner, who wrote it with the co-stars Kenneth Nkosi and Rapulana Seiphemo. A blend of screwball comedy and road movie, it shows two black youngmen who travel across the country-from Johannesburg thru Durban to Cape Town-in order to arrive in time for a wedding. They pick up an English white tourist (Jodie Whittaker) who had found herself lost in the countryside. Stranded with a broken car in a traditional, rural Afrikaner town, the three protagonists go to what would formerly be a whites-only bar, and get drunk with a bunch of fellow white drinkers. The Afrikaners end up helping the black protagonists to get to Cape Town and, after having shown racial disputes with an invincible good-humour, the film ends in a multiracial festive tone. It is interesting to note that White Wedding is heavily polyglotic, producing an interesting balance of Xhosa, Zulu, English and Afrikaans dialogues.

Sea Point Days is a documentary directed by Capetonian François Verster, a good sample of the work of a new generation of filmmakers. It shows the transformations undergone by one of the formerly white neighbourhoods of Cape Town as told by the people who walk by its promenade and swim in the integrated municipal 
pools. It is a good example of the history of the reappropriation of spaces once racially segregated.

The more experimental Proteus was directed by Canadian filmmaker John Greyson and scripted by South African author Jack Lewis. It is an ingenious fiction film inspired by the record of a eighteenth century episode that took place in the island-prison of Robben, where a Khoikhoi (black) prisoner and a Dutch (white) prisoner develop a love affair. It is a daring project in which sets and costumes mesh time periods and establish historical connections, giving us hints of the roots of racism as well as its homophobic implications. Robben island is the same prison where Nelson Mandela and many other political dissidents were kept for decades. If South African history awaits to be retold, Proteus makes sure that it should not overlook the role of desire in the process.

These films are eloquent examples of a South Africa that has changed, and changed for good.

This issue of Ilha do Desterro gathers works about literature and media in South Africa and are authored by some of the best scholars now active in South Africa. The texts that comprise this issue were grouped in two different sections.

Toward the Past opens with "De la Rey is new ancestor of Afrikaner youth", a piece by poet Antjie Krog, reputedly one of the most important poets of the Afrikaans language. Krog became an international celebrity as the author of Country of My Skull, a compelling, beautifully crafted report on the works of the Truth and Reconciliation Commission led by bishop Desmond Tutu in the 1990s. ${ }^{7}$ In this text for Ilha do Desterro, Krog chronicles the revival of De la Rey, a famous military leader of the Boer Wars, that took 
place between 1880 and 1902. The ballad De la Rey, which became a hit song in the recent years and echoed the disenfranchisement felt by certain Afrikaner communities, was one of the manifestations that led to a turn towards patriotic values. However, what seems to be a mere demonstration of separatist and racist values to outside observers is here turned upside down, as the complexities implied in the choice of that hero, which result in a cultural phenomenon, are acutely analyzed by Krog. ${ }^{8}$ Her poetic endeavour as the spokesperson of a community can be detected in the way she courageously identifies her own positionality: "When I utter the words 'corruption' and 'discrimination', I feel how they die in my Afrikaner mouth".

In her cogent essay "Selected tweentieth and tweentieth-first century representations of tribalism and modernity in South African literature", Annie Gagiano takes us farther back in the past, lays a bridge to contemporaneity and raises the question of how Africans represent themselves. The range of works she analyzes stems from fragments of Khoikhoi literature, an ethnic group that lived in the region of the Cape long before the arrival of Bantu and European groups, to recent autobiographical accounts in English by contemporary African authors.

In "Vindicating Capital: Heroes and Villains in a Lions' Trail", Adam Haupt and Håvard Ovesen track the history of one of the most popular songs of all time, known throughout the world as The Lion Sleeps Tonight. A rigorous report on a mass media event of global proportions, their text explores the political implications that kept the original authors of the song deprived of rights and recognition. One more story that needed to be retold in the new South Africa.

"History and the 'imagination of men's hearts' in Mike Nicol's Horseman", by Ian-Malcolm Rijsdijk, is a sample of the finest literary criticism in contemporary South Africa. He delves into Nicol's works and shed new lights on the literary landscape of South Africa. 
This section ends with a comprehensive essay by one of the most important film historians in South Africa: Lucia Saks. Her work, "A Tale of Two Nations", deals with two films that represent different versions of South African film history. The first one is De Voortrekkers (Harold Shaw, 1916), the Afrikaner film that was deeply influenced by Griffith's Birth of a Nation and which is considered by many as the founding work of South African cinema. The second is Come See the Bioscope (1997), a contemporary documentary film that tells the story of Solomon Tshekisho Plaatje, a black intellectual who was also a pioneer of cinema, and which shows the role of black Africans in the building of what can be called today South African cinema. Saks articulates these apparently antagonist views of history and shows us the ways South Africa is now facing its own past in order to build the post-apartheid era.

The second section of this issue of Ilha was dubbed From the Future, and it opens again with another short chronicle by Antjie Krog, "Soccer steps in where politics fail to create a new vocabulary". Her account of a soccer game as viewed among the crowds in front of widescreens in downtown Cape Town exudes a feeling of compassion towards the trials faced by the South African people. Krog defines the democratic elections in the 1990s as "South Africa's first act of trust" and compares them to the Soccer World Cup as probably being their second. From reading Krog's text, we realize that the World Cup in South Africa was a landmark event whose aftermath has just begun.

In his turn, Brazilian scholar Anderson Bastos Martins develops an astute approach of Nadine Gordimer's work and life, in the essay "A house on sale for a homecoming". He follows the trajectories of some of Gordimer's characters and pinpoints some moments of 
her biography, in order to understand her positionalities regarding nation, exile and her definition of what it means to be an African.

In "Post-apartheid cinema: a thematic and aesthetic exploration of selected short and feature films", Martin P. Botha competently lists some of the most important films produced in South Africa in the recent years and explores tendencies and directions. The author examines the changes undergone by South African cinema when the old film subsidy system, which supported the existence of the film industry under apartheid, ceased to exist. Instead of lamenting the change, Botha sees new opportunities in the near future, which can already be assessed by the production he analyzes. Botha has marked his position as one of the most prolific and talented researchers of his generation, having recently published the comprehensive South African Cinema: 1886-2010 (Bristol: Intellect, 2010).

In "Betraying and delivering: filming Disgrace", Ian Glenn centers his focus on the recent adaptation of J. M. Coetzee's novel Disgrace, directed for the screen by Steve Jacobs in 2008. Glenn argues that the film "betrays" the original text; however, if on one hand it contradicts the novel and moves towards a more positive portrayal of the country, on the other it is more successful in its depiction of violence in rural South Africa. Glenn manages to value the qualities of each medium in order to grasp a riveting portrayal of the country.

"The Meaning of South African Media's Expansion into the Rest of African Space", by Musa Ndlovu, deals with the role played by South Africa in the landscape of the media in the continent. It is a fact that many African countries have become importers of South African radio and television programming-especially the countries in which English is a prominent language. With competence, Ndlovu views that expansion from a double perspective: he examines the consequences of an subimperialist attitude that views neighboring 
countries as mere consummers of media products and, on the other hand, he values the possibilities of cooperation that are in store in the near future.

In her article "Digital cinema: an alternative model for postapartheid cinematic production and consumption?", Astrid TreffryGoatley, a scholar at the University of KwaZulu-Natal, discusses new technologies and displays a wide panorama of the present state of South African cinema. Treffry-Goatley also displays a close understanding of Brazilian cinema as she compares trends of the film industries in both countries.

This issue of Ilha do Desterro concludes with two book reviews. The first was written by Chris Broodryk, a young scholar from the University of Pretoria, and it deals with Jacqueline Maingard's book South African National Cinema. The second, about J. M. Coetzee's novel Summer, was written by Marilia Fatima Bandeira, who studies at Universidade de São Paulo and has kept a productive correspondence with the South African novelist.

São Paulo, 2011.

\section{Notes}

1. As seen in In Darkest Hollywood: Cinema and Apartheid, a documentary by Peter Davis, 1993.

2. New York: Grove Press, 1990.

3. Country of my Skull. Johannesburg: Random House, 2002, 293.

4. The other official languages are Ndebele, Northern Sotho, Sotho, Swazi, Tswana, Tsonga and Venda.

5. Racial classification under apartheid was more specific and grouped people in more than ten different categories.

6. At UCT, capoeira is taught by young Brazilian mestres.

7. Country of My Skull inspired the controversial film In My Country, directed by John Boorman in 2004. 
8. That phenomenon was brilliantly shown in a scene of White Wedding, when the black protagonists get trapped in the Afrikaner bar and end up singing De la Rey in Afrikaans, to the utter surprise of the (supposedly racist) white bystanders. 
